\title{
Effect of Foliar Spray of Boron and Different Zinc Levels on Growth and Yield of Kharif Greengram (Vigna radiata)
}

\author{
Rajana Praveena*, Gautam Ghosh and Vikram Singh \\ Department of Agronomy, SAM Hgginbottom University of Agriculture Technology and \\ Sciences, Allahabad, India \\ *Corresponding author
}

\section{A B S T R A C T}

\section{Keywords}

Greengram, Boron,

Zinc, Foliar spray,

Growth and yield

Article Info

Accepted:

10 July 2018

Available Online:

10 August 2018

\begin{abstract}
A field experiment was conducted during the kharif season of 2017 in greengram crop (var. PDM-139) at Crop Research Farm, Department of Agronomy, Naini Agricultural Institute, SHUATS, Allahabad (U.P.). The experiment was laid out in Randomized Block Design with consisting of frequency of foliar spray $(0.2 \%)$ of 4 boron levels at different days of intervals (No. application control, 0.2\%, foliar spray at 20 and 35 DAS and $0.2 \%$ foliar spray of borax at both stage (20 and 35 DAS) with basal application of 3 zinc levels (0kg control, $2.5 \mathrm{~kg} \mathrm{ha}^{-1}, 5 \mathrm{~kg} \mathrm{ha}^{-1}$. The experimental results revealed that growth parameters viz. plant height $(64.16 \mathrm{~cm})$, no. of branches per plant $(7.80)$, no. of nodules (20.60), plant dry weight (8.48), Crop growth rate (CGR) $\left(0.33 \mathrm{~g} \mathrm{~m}^{-2}\right.$ day $\left.^{-1}\right)$ and yield attributes viz. no. pods per plant (23.86), no. of grains per pod (12.40), grain yield (2.18t $\left.\mathrm{h}^{-1}\right)$, straw yield $\left(2.96 \mathrm{t} \mathrm{ha}^{-1}\right)$ were significantly recorded higher under treatment $\mathrm{T}_{12} 20$ and $35 \mathrm{DAS}\left(0.2 \%\right.$ foliar spray) of boron $+5.0 \mathrm{~kg} \mathrm{ha}^{-1}$ of zinc.
\end{abstract}

\section{Introduction}

Pulses are least preferred by farmers because of high risk and less remunerative than cereals; consequently, the production of the pulses is significantly low to meet the demand of pulses. Majority of Indian population is vegetarian, pulses are cheap and best source of protein for Indian diet. It contains 20-25 per cent protein, which is more than two times of cereals. India importing about 3 million tonnes and the future demand of pulses by 2015 will be 27.0 million tones (Singh et al., 2011).

Green gram locally called as moong or mung [Vigna radiata (L.) Wilczek]. It belongs to the family leguminaceae so it has the capacity to fix atmospheric nitrogen. It's one of the important kharif pulse crops of India which can be grown as catch crop between rabi and kharif seasons. India alone accounts for $65 \%$ of its world acreage and $54 \%$ of the total production. It is grown on about 3.50 mha in the country mainly in Rajasthan, Maharashtra, Andhra Pradesh, Karnataka, Orissa and Bihar. A phenomenal increase in area, production and productivity has occurred since 1964-65. The area has increased from 1.99 million ha in 1964-65 to 3.54 million ha in 2010- 2011. The production has increased from 0.60 million tonnes to 1.81 million tonnes during the same period. Throughout the India, the mungbean is 
used for different purposes. The major portion is utilized in making dal, soup, sweets and snacks (Anonymous, 2012). Mungbean is an excellent source of protein $(25 \%)$ with high quality of lysine $(460 \mathrm{mg} / \mathrm{g})$ and tryptophan $(60 \mathrm{mg} / \mathrm{g})$. It also has remarkable quantity of ascorbic acid when sprouted and also have riboflavin $(021 \mathrm{mg} / 100 \mathrm{~g})$ and minerals (3.84 W $100 \mathrm{~g}$ ). The total area under pulses is 23.63 mha with an annual production of $14.76 \mathrm{M}$ tonnes in the country. In India green gram occupies 3.4 million hectare area and contributes to 1.4 million tonnes in pulse production (Anonymous. 2010-11). Mungbean contributes $14 \%$ in total pulse area and $7 \%$ in total pulse production in India. The low productivity of mungbean may be due to nutritional deficiency in soil and imbalanced external fertilization (Awomi et al., 2012).

Micronutrients are essential for plant growth; Zinc is one of the seven pillars of nutrition and is needed for the growth of plant, animals and humans. The amount of zinc in pasture and forage is very little and varies from 20 to 30 $\mathrm{mg} \mathrm{kg}-\mathrm{i}$ in soil. Zinc is necessary to activate many enzymes, enzymes that are activated by the zinc are Tryptophan synthetase superoxide dismutase and dehydrogenases. Lack of zinc causes deficiency in formation of RNA and protein. Therefore, the plant with lack of zinc is poor in amount of protein. Foliar spraying of micronutrients for the growth of greengram and its quality in industry views is necessary for growth and quality of greengram. Renjel (2001) showed that zinc fertilizer application causes root and shoot growth during the growing season and therefore, lead to increased seed yield. Spraying the leaves with the nutrient elements is one of the methods of plant supply. Although the leaves and shoots can absorb nutrients as well as water, gas through the stomata, leaf spraying method in addition to the rapid response, will also save money. The fertilization procedure in addition to economic aspects and the effectiveness of the immediate environment in order to achieve sustainable agriculture is also very effective and useful (Fard et al., 2012).

Micronutrients like boron is one of the mineral nutrients required for normal plant growth. The most important functions of boron in plants are thought to be its structural role in cell wall development, cell division, seed development and stimulation or inhibition of specific metabolic pathways for sugar transport and hormone development (Ahmed et al., 2009). Furthermore, boron deficiency causes decrease in pollen grain count, pollen germination etc. It also influences growth parameters and filling up of seeds. It is usually accepted that boron availability is decreased under dry soil conditions. Thus, boron deficiency is often associated with dry weather and low soil moisture conditions. This behavior may the related to restricted release of boron from organic complexes which ultimately impaired ability of plants to extract $B$ from soil due to lack of moisture in the rhi7osphere. Even of B levels in soil is high, then also low soil moisture impairs transport of B to absorbing root surfaces (Das, 2011).

\section{Materials and Methods}

A field experiment was conducted during the kharif season of 2017 in greengram crop at Crop Research Farm, Department of Agronomy, Naini Agricultural Institute, SHUATS, Allahabad (U.P.). The experiment consisted of frequency of foliar spray $(0.2 \%)$ of 4 boron levels at different days of intervals (No. application control, $0.2 \%$, foliar spray at $20 \& 35$ DAS and $0.2 \%$ foliar spray of borax at both stage (20 and 35 DAS) with basal application of 3 zinc levels ( $0 \mathrm{~kg}$ control, $2.5 \mathrm{~kg}$ $\mathrm{ha}^{-1}, 5 \mathrm{~kg} \mathrm{ha}{ }^{-1}$ laid out in a Randomized Block Design with twelve treatment combinations, replicated thrice. The soil of the experimental field was sandy loam in texture with $\mathrm{pH}$ 7.6, low in organic carbon $0.230 \%$, available $\mathrm{P}$ 
(9.4 $\left.\mathrm{kg} \mathrm{ha}^{-1}\right)$ and available $\mathrm{K}\left(187 \mathrm{~kg} \mathrm{ha}^{-1}\right)$, available zinc $(0.88 \mathrm{ppm})$, available B (0.24ppm), Nitrogen, Phosphorus and Potassium were applied through urea, DAP (Di Ammonium Phosphate) and muriate of potash, respectively. Different doses of zinc were applied basally according to the treatment during the sowing itself. Foliar spray of borax at $0.2 \%$ by using knap-sack sprayer was done at 20, 35 DAS, both at 20 and 35 DAS. All the growth and yield attributes were recorded using standard procedure and grain yield was calculated at $12 \%$ moisture content. The crop growth rate (CGR) was calculated using the standard procedure and formulae.

\section{Results and Discussion}

\section{Effect of growth attributes on greengram}

Among the treatments $\mathrm{T}_{12} 20 \&$ 35DAS $(0.2 \%$ foliar spray) of boron+5.0kg ha-1 of zinc significantly produced higherplant height $(64.16 \mathrm{~cm})$, no. of branches per plant $(7.80)$, no. of nodules (20.60), plant dry weight (8.48) at 60 DAS, Crop growth rate (CGR) (0.33) at 30-45 DAS and yield attributes viz. no. pods per plant (23.86), no. of grains per pod (12.40), grain yield $\left(2.18 \mathrm{t} \mathrm{h}^{-1}\right)$, straw yield $\left(2.96 \mathrm{t} \mathrm{ha}^{-1}\right)$.

Foliar application of boron $(0.2 \%$ through borax) increased the vegetative growth in terms of plant height, Crop growth rate and also increased the no. of nodules per plant Foliar application $0.2 \%$ of borax increased the total dry matter production and nodules weight in greengram.

These results are in similar finding was reported by Mandal et al., (2005) and Pandey and Gupta (2012). This might be due to quick availability of boron to crop during the entire growing season. Boron plays an important role in tissue differentiation and carbohydrate metabolism. It is also a constituent of cell membrane and essential for cell division, maintenance of conducting tissue with regulatory effect on other element. It is also necessary for sugar translocation in plant and development of new cell in meristematic tissue. The increase in plant height under zinc treatment may be due to its effect in the metabolism of growing plants, which may effectively explain the observed response of zinc application. Favourable response of zinc application on plant height the results are in similar finding of (Khalil and Prakash 2014 and Shanti et al., 2008).

\section{Effect of yield and yield attributes on greengram}

Among the yield and yield attributes treatment $\mathrm{T}_{12-} 20$ and $35 \mathrm{DAS}$ (0.2\% foliar spray) of boron $+5.0 \mathrm{~kg} \mathrm{ha}^{-1}$ of zinc significantly produced higher yield attributes viz. no. pods per plant (23.86), no. of grains per pod (12.40), grain yield $\left(2.18 \mathrm{t} \mathrm{h}^{-1}\right)$, straw yield $\left(2.96 \mathrm{t} \mathrm{ha}^{-1}\right)$.

Foliar application of 0.2 per cent borax at preflowering (35DAS) was found to enhance yield and yield attributes of greengram significantly over control.

This is might due to application of borax at 0.2 per cent foliar spray at pre flowering significantly increased all yield attributing character in greengram viz., number of pod plant $^{-1}$, seed pod ${ }^{-1}$, test weight, seed and straw yield. Enhanced vegetative growth in terms of number of branches per plant provided more sites for translocation of photosynthates and ultimately resulted in increment in yield attributes (Table 1 and 2).

The beneficial effect of boron on yield attributes may be due to flower development pollen grain formation, pollen viability, pollen tube growth for proper pollination and seed development. The results are in similar findings with those of (Ram et al., 2017). 
Table.1 Effect of foliar spray of boron and different levels of zinc on growth attributes of Greengram at different days of intervals

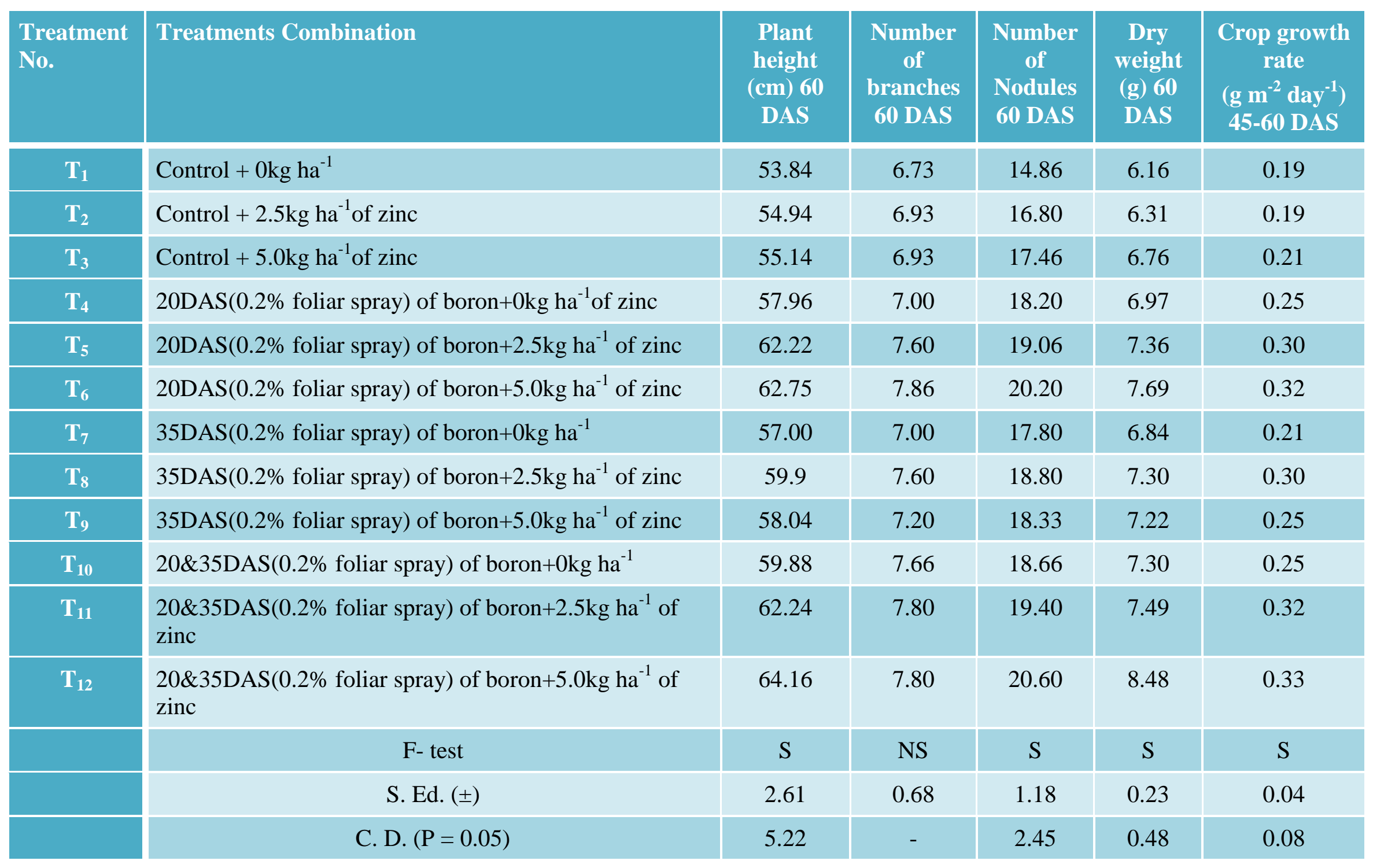


Table.2 Effect of foliar spray of boron and different levels of zinc on yield and yield attributes of Greengram

\begin{tabular}{|c|c|c|c|c|c|}
\hline $\begin{array}{l}\text { Treatment } \\
\text { No. }\end{array}$ & Treatments Combination & $\begin{array}{c}\text { Number } \\
\text { of Pod } \\
\text { plant }^{-1}\end{array}$ & $\begin{array}{l}\text { Number of } \\
\text { grain Pod }^{-1}\end{array}$ & $\begin{array}{c}\text { Grain } \\
\text { yield } \\
\left(\mathbf{t ~ h a}^{-1}\right)\end{array}$ & 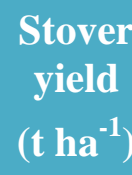 \\
\hline $\mathbf{T}_{1}$ & Control $+0 \mathrm{~kg} \mathrm{ha}^{-1}$ & 17.80 & 11.66 & 1.46 & 1.83 \\
\hline $\mathbf{T}_{2}$ & Control $+2.5 \mathrm{~kg} \mathrm{ha}^{-1}$ of zinc & 18.20 & 11.66 & 1.59 & 2.04 \\
\hline $\mathbf{T}_{\mathbf{3}}$ & Control $+5.0 \mathrm{~kg} \mathrm{ha}^{-1}$ of zinc & 18.26 & 11.93 & 1.69 & 2.36 \\
\hline $\mathbf{T}_{4}$ & $20 \mathrm{DAS}(0.2 \%$ foliar spray $)$ of boron $+0 \mathrm{~kg} \mathrm{ha}^{-1}$ of zinc & 19.66 & 12.06 & 1.78 & 2.46 \\
\hline $\mathbf{T}_{5}$ & $20 \mathrm{DAS}\left(0.2 \%\right.$ foliar spray) of boron $+2.5 \mathrm{~kg} \mathrm{ha}^{-1}$ of zinc & 20.33 & 12.20 & 1.88 & 2.69 \\
\hline $\mathrm{T}_{6}$ & $20 \mathrm{DAS}\left(0.2 \%\right.$ foliar spray) of boron $+5.0 \mathrm{~kg} \mathrm{ha}^{-1}$ of zinc & 22.86 & 12.33 & 2.16 & 2.90 \\
\hline $\mathbf{T}_{7}$ & $35 \mathrm{DAS}\left(0.2 \%\right.$ foliar spray) of boron $+0 \mathrm{~kg} \mathrm{ha}^{-1}$ & 18.93 & 11.93 & 1.74 & 2.43 \\
\hline $\mathbf{T}_{8}$ & $35 \mathrm{DAS}\left(0.2 \%\right.$ foliar spray) of boron $+2.5 \mathrm{~kg} \mathrm{ha}^{-1}$ of zinc & 20.33 & 12.06 & 1.86 & 2.68 \\
\hline $\mathrm{T}_{9}$ & $35 \mathrm{DAS}\left(0.2 \%\right.$ foliar spray) of boron $+5.0 \mathrm{~kg} \mathrm{ha}^{-1}$ of zinc & 20.00 & 12.00 & 1.85 & 2.25 \\
\hline $\mathbf{T}_{10}$ & $20 \& 35 \mathrm{DAS}\left(0.2 \%\right.$ foliar spray) of boron $+0 \mathrm{~kg} \mathrm{ha}^{-1}$ & 20.33 & 12.06 & 1.85 & 2.25 \\
\hline $\mathbf{T}_{11}$ & $20 \& 35 \mathrm{DAS}\left(0.2 \%\right.$ foliar spray) of boron $+2.5 \mathrm{~kg} \mathrm{ha}^{-1}$ of zinc & 22.20 & 12.20 & 2.00 & 2.79 \\
\hline \multirow[t]{4}{*}{$\mathbf{T}_{12}$} & $20 \& 35 \mathrm{DAS}\left(0.2 \%\right.$ foliar spray) of boron $+5.0 \mathrm{~kg} \mathrm{ha}^{-1}$ of zinc & 23.86 & 12.40 & 2.18 & 2.96 \\
\hline & F- test & $\mathrm{S}$ & $\mathrm{S}$ & $\mathrm{S}$ & $\mathrm{S}$ \\
\hline & S. Ed. $( \pm)$ & 0.93 & 0.18 & 0.16 & 0.10 \\
\hline & CD. $(P=0.05)$ & 1.94 & 0.38 & 0.33 & 0.20 \\
\hline
\end{tabular}


Higher number of pods per plant with zinc application could possibly be explained by the fact that zinc application increased the realisation of flower into pods. The highest number of seeds per pod (6.90) was however recorded under basal application of zinc @ $5.5 \mathrm{~kg} \mathrm{ha}^{-1}$. Seeds per pod were also increased with zinc application over control which might be due to the role of zinc in seed setting. Zinc application on straw yield of green gram might be due to its direct influence on auxin production which in turn enhanced the elongation processes of plant development. The results are in similar findings with those of (Partha et al., 2017, Ghildayal et al., 1978 and Ahmadi et al., 2010, Singh and Badhoria 1984 and Marschner, 1995).

On the basis of above findings it can be concluded that the grain yield $\left(2.18 \mathrm{t} \mathrm{ha}^{-1}\right)$, straw yield (2.96t ha-1) and other growth and yield attributes were found to be the best with treatment $\mathrm{T}_{12}-20$ and 35DAS $(0.2 \%$ foliar spray) of boron $+5.0 \mathrm{~kg} \mathrm{ha}^{-1}$ of zinc

\section{References}

Ahmad W, Niaz A, Kanwal S, Rahmatullah and Rashed M. K. (2009). Role of boron in plant growth: a review. Journal of Agriculture Research 47(3): 329-338.

Ahmadi, M. (2010). Effect of zinc and nitrogen fertilizer rates on yield and yield components of oilseed rape (Brassica napus L.). World Appl. Sci. J., 10(3): 298-303.

Awomi TA, Singh AK, Kumar M, Bordoloi LJ (2012). Effect of phosphorus, molybdenum and cobalt nutrition on yield and quality of mungbean (Vigna radiata L.) in acidic soil of Northeast India. Indian J Hill Farm 25(2): 22-26.

Das D. K. (2011). Micronutrients: their behavior in soil and plants. Kalyani publisher, New Delhi. Pp. 165-168
Fard, S. R., Khourgami, A., Rafee, M. and Nasrollahi, H. (2012). Study the effect of Zinc spraying and plant density on seed yield and morphological characteristics of Greengram. Annals of Biological Research, 3 (8): 4166-4171.

Ghildiyal, M.C., Tomar, O.P.S. and Sirohi, G.S. (1978). Response of cowpea genotypes to zinc in relation to photosynthesis, nodulation and dry matter distribution. Plant Soil, 49: 505516.

Khalil Khan and Ved Prakash (2014). Effect of rhizobial inoculation on growth, yield, nutrient and economics of summer urdbean (Vigna mungo L.) in relation to zinc and molybdenum. International Journal of Advanced Research in Chemistry and Chemical Engineering. 125.

Marschner, H. (1995). Mineral nutrition of higher Plants, $2^{\text {nd }}$ edn. Academic Press, London, UK.

Pandey, N. and Gupta, B. (2012). The impact of foliar boron sprays on reproductive biology and seed quality of black gram. Plant Nutrition and Stress Physiology Laboratory, Department of Botany. University of Lucknow.

Partha Deb Roy, Lakshman K., Narwal R.P., Malik R.S. and Sushanta Sah (2017) Green gram (Vigna radiata L.) Productivity and Grain Quality enrichment through Zinc Fertilization. Int.J.Curr.Microbiol.App.Sci 6(6): 643648.

Ram, Chena, Singh, Devendra and Jat, Bhanwar Lal (2017). Effects of different phosphorus levels and frequency of boron levels on growth and yield of greengram. Adv. Res. J. Crop Improv, 8(1): 49-61.

Rengel, (2001), Communication in soil science and plant analysis, 32, 11631186. 
Shanti, M., Babu, B.P., Prasad, B.R. and Minhas, P.S. (2008). Effect of zinc on blackgram in rice-blackgram cropping system of coastal saline soils. Legume Res., 31(2): 79-86.
Singh, B. and Badhoria, B.S. (1984). Response of green gram to potassium and zinc application. J. Agri. Sci., 102: $253-255$.

\section{How to cite this article:}

Rajana Praveena, Gautam Ghosh and Vikram Singh. 2018. Effect of Foliar Spray of Boron and Different Zinc Levels on Growth and Yield of Kharif Greengram (Vigna radiata). Int.J.Curr.Microbiol.App.Sci. 7(08): 1422-1428. doi: https://doi.org/10.20546/ijcmas.2018.708.163 